\title{
Graft-versus-host disease can be separated from graft-versus-lymphoma effects by control of lymphocyte trafficking with FTY720
}

\author{
Yong-Mi Kim, ${ }^{1}$ Teviah Sachs, ${ }^{1}$ Wannee Asavaroengchai,${ }^{1}$ Roderick Bronson, ${ }^{2,3}$ \\ and Megan Sykes ${ }^{1}$
${ }^{1}$ Transplantation Biology Research Center, Massachusetts General Hospital, Harvard Medical School, Boston, Massachusetts, USA
${ }^{2}$ Department of Pathology, Harvard Medical School, Boston, Massachusetts, USA
${ }^{3}$ Department of Biological Sciences, Tufts University School of Veterinary Medicine, Hospital for Large Animals, \\ North Grafton, Massachusetts, USA
}

\begin{abstract}
Graft-versus-host disease (GvHD) mediated by donor T cells recognizing host alloantigens is associated with beneficial graft-versus-tumor effects in recipients of allogeneic hematopoietic cell transplants. Since leukemias and lymphomas reside largely within the lymphohematopoietic system, we have proposed that the desired graft-versus-leukemia or graft-versus-lymphoma effect can be separated from the complication of GvHD by confinement of the graft-versus-host alloresponse to the lymphohematopoietic tissues. Since the new sphingosine-1-phosphate receptor agonist immunosuppressive drug FTY720 leads to trapping of T cells in secondary lymphoid tissues, we evaluated the possibility that this drug could diminish GvHD, a disease involving epithelial target tissues, while permitting a beneficial alloresponse to take place within the lymphohematopoietic system, leading to graft-versus-lymphoma effects. We demonstrate here that FTY720 markedly reduces GvHD in a clinically relevant, haploidentical strain combination, while permitting antitumor effects against a T cell lymphoma of unshared host MHC haplotype to proceed unhindered. These results establish a potential new immunotherapeutic approach to separating graft-versus-leukemia effects from GvHD.

J. Clin. Invest. 111:659-669 (2003). doi:10.1172/JCI200316950.
\end{abstract}

\section{Introduction}

Allogeneic hematopoietic cell transplantation (HCT) is often the only potentially curative therapy for hematological malignancies and other diseases $(1,2)$. A major obstacle impeding the success and wider application of HCT is graft-versus-host disease (GvHD) (3). Significant acute GvHD (grades II-IV) occurs in $25-60 \%$ of HLA-identical related-donor HCT and in $45-70 \%$ of matched unrelated transplant recipients (4-6). The incidence is unacceptably high when major HLA barriers are traversed (7). Consequently, approximately $50 \%$ of patients who might benefit from HCT do not have this therapeutic option, due to the unavailability of an appropriately

Received for publication September 18, 2002, and accepted in revised form January 21, 2003.

Address correspondence to: Megan Sykes, Transplantation Biology Research Center, Bone Marrow Transplantation Section, MGH-East, 13th Street, Building 149-5102, Harvard Medical School, Boston, Massachusetts 02129, USA. Phone: (617) 726-4064; Fax: (617) 724-9892;

E-mail: Megan.Sykes@tbrc.mgh.harvard.edu.

Conflict of interest: The authors have declared that no conflict of interest exists.

Nonstandard abbreviations used: hematopoietic cell transplantation (HCT); graft versus host $(\mathrm{GvH})$; graft-versus-host disease (GvHD); graft versus leukemia/lymphoma (GvL); donor leukocyte infusion (DLI); bone marrow transplant (BMT); bone marrow cell (BMC); white blood cell (WBC); biotin (Bio); spleen cell (SPC); median survival time (MST); cytotoxic T lymphocyte (CTL). matched related or unrelated donor. The prophylactic use of immunosuppressive drugs such as cyclosporine A, prednisone, and methotrexate $(3,8-13)$ has not successfully eliminated GvHD, even in HLA-identical allogeneic HCT $(14,15)$. One of the most effective approaches to GvHD prophylaxis, T cell depletion of the donor inoculum, is associated with increased risks of graft failure and relapse $(6,8,16,17)$. Experimental $(18,19)$ and clinical $(20-22)$ data indicate that stronger graft-versus-leukemia/lymphoma (GvL) effects are obtained in the presence of the stronger graft-versus-host $(\mathrm{GvH})$ alloreactivity associated with extensive MHC mismatches. Most individuals have haploidentical relatives who could potentially serve as HCT donors. Thus, efforts have been made to develop a safe approach to performing haploidentical HCT (23-25). However, the success of these approaches has been limited by GvHD and, when this is prevented by $\mathrm{T}$ cell depletion of the donor inoculum, by delayed immune reconstitution.

We have proposed that confining the GvH alloresponse to the lymphohematopoietic system could provide an approach to separating GvHD and GvL across MHC barriers. This suggestion was based on our observations of an association between delayed administration of donor lymphocyte infusions to established mixed chimeras and a $\mathrm{GvH}$ alloresponse that converts mixed chimeras to full chimeras $(26,27)$ and mediates GvL effects (28) without causing GvHD. 
We have proposed that this confinement of the GvH alloresponse to the lymphohematopoietic system reflects the recovery from conditioning-induced inflammation by the time of donor lymphocyte infusion (DLI), and that such inflammation in the epithelial GvHD target tissues plays an important role in inducing GvH-reactive $\mathrm{T}$ cells to leave the lymphohematopoietic system and traffic to these target tissues (27). We have initiated clinical trials based on this concept and have indeed observed potent GvL effects in patients receiving DLI following induction of mixed chimerism. This has been achieved with nonmyeloablative conditioning that includes initial $\mathrm{T}$ cell depletion of the donor inoculum in vivo in order to minimize the $\mathrm{GvH}$ reaction at the time when conditioning-induced inflammation is present $(29,30)$. Thus, mixed chimerism is induced with a regimen that includes donor $\mathrm{T}$ cell depletion, and immunotherapy is given in the form of DLI several weeks or months later. A limitation of this approach is that, while the subsiding of conditioning-induced inflammation depends on the delay before administration of DLI as immunotherapy, many hematologic malignancies are rapidly progressive, making this delay undesirable. Thus, it would be desirable to develop an approach to confining the $\mathrm{GvH}$ alloresponse to the lymphohematopoietic system even in the presence of such inflammation, so that optimal GvL effects could be obtained immediately following HCT.

FTY720 (2-amino-2-(2-[4-octylphenyl]ethyl)-1,3propanediol hydrochloride) (31), hereafter referred to as FTY, is a novel immunosuppressive drug that is a metabolite of the ascomycete Isaria sinclairii and has shown promise alone or in combination therapy in various rodent, canine, and primate organ transplantation and autoimmune disease models (32-38). It has also been tested and has been well tolerated in human phase I and phase II trials (39) as chronic immunosuppressive therapy. FTY has also shown GvHDinhibitory activity in a rat model in which spleen cells were transplanted from a parental strain into $F_{1}$ rats treated with $200 \mathrm{mg} / \mathrm{kg}$ cyclophosphamide (40) and in a rat small-bowel transplant model (41).

Recent findings suggest that FTY serves as a sphingosine-1-phosphate receptor agonist that acts on $\mathrm{T}$ cell $G$ protein-coupled receptors $(42,43)$ to influence the migration of lymphocytes, resulting in trapping in the secondary lymphoid organs, diminished organ infiltration, and prevention of allograft rejection $(33,38$, 44). We hypothesized that FTY could diminish GvHDassociated tissue infiltration while permitting antitumor effects to proceed unhindered within the lymphohematopoietic system, thus providing an approach to influencing lymphocyte trafficking so that $\mathrm{GvH}$ and GvL can be separated, even in the presence of conditioning-induced inflammation. We used a clinically relevant, haplotype-mismatched bone marrow transplant (BMT) model and a T cell lymphoma to demonstrate that this is in fact the case.

\section{Methods}

Animals. Female and male B6D2F1 (C57BL/ $6 \times \mathrm{DBA} / 2$, $\left.\mathrm{F}_{1} ; \mathrm{H} 2^{\mathrm{bxd}}\right)$ and $\mathrm{C} 3 \mathrm{D} 2 \mathrm{~F} 1\left(\mathrm{C} 3 \mathrm{H} \times \mathrm{DBA} / 2, \mathrm{~F}_{1} ; \mathrm{H} 2^{\mathrm{kxd}}\right)$ mice were purchased from The Jackson Laboratory (Bar Harbor, Maine, USA) and used at 8-12 weeks of age. All mice were housed in sterilized microisolator cages and received autoclaved feed and autoclaved drinking water. All manipulations were performed in a laminar-flow hood.

Preparation of bone marrow cells and spleen cells. Bone marrow was harvested and single-cell suspensions were prepared as described previously (45). Donor spleens were harvested and gently teased in ammonium chloride potassium-lysing buffer (BioWhittaker Inc., Walkersville, Maryland, USA). Single-cell suspensions were filtered through nylon mesh.

Induction of $\mathrm{G} v H D$. Recipient B6D2F1 mice were lethally irradiated $\left(9.75 \mathrm{~Gy},{ }^{137} \mathrm{Cs}\right.$ source) and reconstituted within 4-8 hours by a single 1 - $\mathrm{ml}$ i.v. inoculum containing $5 \times 10^{6}$ allogeneic C3D2F1 bone marrow cells (BMCs) and $1 \times 10^{6}$ to $3 \times 10^{6} \mathrm{C} 3 \mathrm{D} 2 \mathrm{~F} 1$ spleen cells (GvHD group), or containing $5 \times 10^{6} \mathrm{~B} 6 \mathrm{D} 2 \mathrm{~F} 1 \mathrm{BMCs}$ with or without $1 \times 10^{6} \mathrm{~B} 6 \mathrm{D} 2 \mathrm{~F} 1$ spleen cells (syngeneic control group). To avoid bias from cage-related effects, animals were randomized before and after BMT as described previously (46).

Assessment of $G v H D$. Transplanted animals were monitored for 30,100, or 114 days after BMT by an observer without knowledge of which treatment group the animals, which were randomized in different cages, belonged to. Body weights were measured before transplantation and daily from the day of transplantation until the end of drug administration, and then twice each week until the day of sacrifice. Animals were scored for clinical evidence of GvHD by assessment of changes in skin (alopecia and inflamed or scaly skin), generalized signs (ruffled fur texture, hunched posture, and inflammation of the eyes), and diarrhea. Each parameter was scored as follows: $0=$ normal, $1=$ mild, $2=$ moderate, 3 = severe; for scoring of eye inflammation, $4=$ eyes very severely inflamed, $5=$ eyes very severely inflamed and closed; maximum total score $=11$.

Histopathology. For histopathological analysis of GvHD target tissues, carcasses were saved after death. Samples were collected from small and large bowel, lung, liver, and skin (from the abdomen), and fixed in 10\% formalin or Bouin's solution. The preserved tissue samples were embedded in paraffin, cut into 5 - $\mu \mathrm{m}$-thick sections, and stained with $\mathrm{H} \& \mathrm{E}$ for histological examination. Slides were coded without reference to mouse type or prior treatment status and were systematically examined by a pathologist (R. Bronson) without knowledge of the treatment of the animals.

Assessment of engraftment and chimerism. To determine the levels of donor-type hematopoietic reconstitution, we analyzed chimerism in white blood cells (WBCs) by two-color flow cytometry using a FACScan flow cytometer (Becton Dickinson Immunocytometry Systems, Mountain View, California, USA). Peripheral blood was collected into heparinized Eppendorf tubes 
(Brinkmann Instruments Inc., Westbury, New York, USA) and subjected to deionized-water lysis. For double staining, $1 \times 10^{6} \mathrm{WBCs}$ were incubated in the presence of directly FITC-conjugated or biotin-conjugated (Bioconjugated) or unlabeled mAb's for 30 minutes at $4^{\circ} \mathrm{C}$. Development of Bio-labeled mAb's was performed by subsequent incubation with phycoerythrin-conjugated avidin for 10 minutes. To reduce nonspecific binding, $10 \mu \mathrm{l}$ of mAb 2.4G2 (anti-Fc $\gamma$-RII receptor, i.e, CDw32) (47) hybridoma supernatant was added to all tubes. The following antibodies were used for chimerism analyses in various cell lineages: anti-CD4-FITC, anti-CD8 $\beta$ FITC, anti-B220-FITC (all purchased from Pharmingen, San Diego, California, USA), and anti-Mac-1-FITC (Caltag Laboratories, Burlingame, California, USA). Nonreactive control mAb's HOPC-FITC and HOPC-Bio (mouse IgG2a prepared in our laboratory) were used as negative controls. Forward-angle and $90^{\circ}$ light-scatter properties were used to distinguish lymphocytes, monocytes, and granulocytes in peripheral WBCs. We detected the recipients' cells $\left(\mathrm{H}_{2} \mathrm{D}^{\mathrm{b}}\right)$ by KH95-Bio (Pharmingen) and the donors' cells $\left(\mathrm{H}_{2} \mathrm{~K}^{\mathrm{k}}\right)$ by $36-7-5$-Bio (Pharmingen) and distinguished donor and host cells of various lineages. Using the recipient marker KH95Bio, we calculated the relative percentage of recipient cells in a chimera using the formula: $100 \% \times$ (recipient phenotype percentage positive - isotype control) / [(recipient phenotype percentage positive - isotype control) + (recipient phenotype percentage negative - isotype control)]. Subtraction of the relative percentage of recipient cells in a chimera from $100 \%$ yielded the relative percentage of donor cells in a chimera. Using the donor marker 36-7-5-Bio, we calculated the relative percentage of donor cells in a chimera using the formula: $100 \% \times$ (donor phenotype percentage positive - isotype control) / [(donor phenotype percentage positive - isotype control) + (donor phenotype percentage negative isotype control)]. Exclusion of dead cells was performed by propidium iodide staining and live gating on propidium iodide-negative cells. Ten thousand events were collected and analyzed. The different peripheral blood leukocyte populations were distinguished by their forward scatter (FSC) and side scatter (SSC) properties: lymphocytes had low FSC and low SSC, granulocytes had high SSC, and monocytes had high FSC and low SSC. EL4 leukemia experiments. We used the EL4 leukemia/ lymphoma model that we have previously described (48). EL4F cells (referred to here as EL4), a subline of B6 $\left(\mathrm{H}^{\mathrm{b}}{ }^{\mathrm{b}}\right) \mathrm{T}$ cell leukemia/lymphoma EL4, were thawed from frozen vials and maintained in culture for 4 days before each experiment, and 5,000 cells were administered on day 0 along with BMCs and spleen cells in a single 1-ml i.v. injection. Carcasses were saved in formalin or Bouin's solution. The presence of tumor at death was determined by gross autopsy and/or histologic observation by an observer and/or pathologist who was unaware of which treatment group the carcasses belonged to, as previously described (44). EL4 cells were detected in lym- phoid tissues by two-color flow cytometry using mAb's against $\mathrm{V} \beta 12$ and Thy 1.2 (Pharmingen).

Adoptive transfer of BMCs and spleen cells from surviving animals in GvL experiments. BMCs and spleen cells were harvested from individual surviving experimental or control animals, and single-cell suspensions were prepared as described above. Lethally irradiated secondary B6D2F1 recipients $(9.75 \mathrm{~Gy})$ were injected intraperitoneally with anti-CD4 mAb GK1.5, anti-Ly2.1 mAb 2.43, and anti-Ly2.2 mAb 116-13.1 on day -1 with respect to the cell transfer. All of the T cell-depleted BMCs and spleen cells from each experimental mouse were administered to a single lethally irradiated, in vivo $\mathrm{T}$ cell-depleted B6D2F1 secondary recipient. For in vitro $T$ cell depletion, single-cell suspensions of BMCs and spleen cells from the individual surviving animals, or $5 \times 10^{6} \mathrm{BMCs}$ and $1 \times 10^{6}$ spleen cells from normal C3D2F1 control mice, were filtered through nylon mesh and depleted of T cells with anti-CD4 mAb GK1.5 (49) and anti-CD8 mAb 2.43 (50) plus low-toxicity rabbit complement, as described previously (51). T cell depletion was analyzed by flow cytometry, and less than $1 \%$ of the cells of the depleted subset remained before DLI. Donor chimerism was followed by FACS analysis.

Preparation of FTY. FTY was kindly provided by Volker Brinkmann (Novartis Pharma AG, Basel, Switzerland) as dry powder and dissolved in sterile distilled water at a concentration of $1 \mathrm{mg} / \mathrm{ml}$. The administration was performed by daily oral gavage at a dose of $6,3,1$, or 0.1 $\mathrm{mg} / \mathrm{kg}$ from day -2 or day 0 until day 29 or day 100 post-BMT as indicated.

Statistical analysis. Survival data were analyzed using the log rank test. Differences between group weights were tested using the nonparametric Mann-Whitney test or Student's $t$ test of means. Chimerism was compared using Student's $t$ test of means.

\section{Results}

Lack of toxicity of FTY in syngeneic BMT recipients. There was no clinical evidence of toxicity in syngeneic BMT recipients receiving FTY at doses of $6,3,1$, or 0.1 $\mathrm{mg} / \mathrm{kg} / \mathrm{d}$ for 29 or 100 days. In mice receiving 3 $\mathrm{mg} / \mathrm{kg} / \mathrm{d}$ for 29 or 100 days, spleen, liver, lung, skin, and large and small bowel did not show any histological evidence of tissue damage (data not shown).

$F T Y$ decreases the mortality of $G v H D$ and reduces clinical $G v H D$. To determine whether FTY could inhibit GvHD, we lethally irradiated male B6D2F1 ( $\left.\mathrm{H} 2^{\mathrm{bxd}}\right)$ mice ( $9.75 \mathrm{~Gy})$ and reconstituted them with either syngeneic bone marrow $\left(5 \times 10^{6}\right.$ cells i.v. $)$ for hematopoietic rescue, or an inoculum of haplotype-mismatched GvHD-inducing allogeneic marrow cells $\left(5 \times 10^{6}\right)$ and spleen cells $\left(1 \times 10^{6}\right)$ from male C3D2F1 $\left(\mathrm{H} 2^{\mathrm{kxd}}\right)$ donors. Three different doses of FTY $(3 \mathrm{mg} / \mathrm{kg}, 1$ $\mathrm{mg} / \mathrm{kg}$, or $0.1 \mathrm{mg} / \mathrm{kg}$ ) or sterile $\mathrm{H}_{2} \mathrm{O}$ as control were administered daily by oral gavage from day 0 until day 29 post-BMT. Mortality of the $\mathrm{H}_{2} \mathrm{O}$-treated GvHD control mice began on day 7 post-BMT, and five of ten mice succumbed by day 13 (Figure 1a). The remaining 


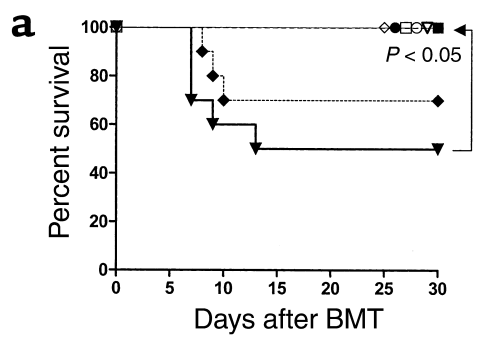

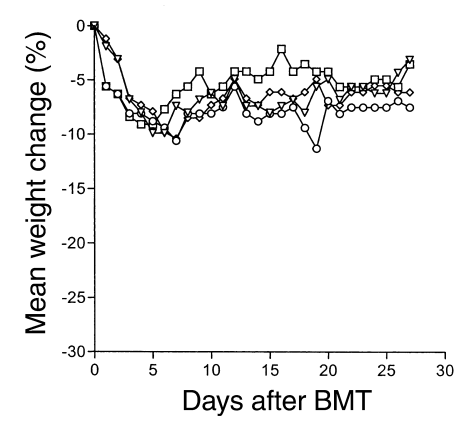

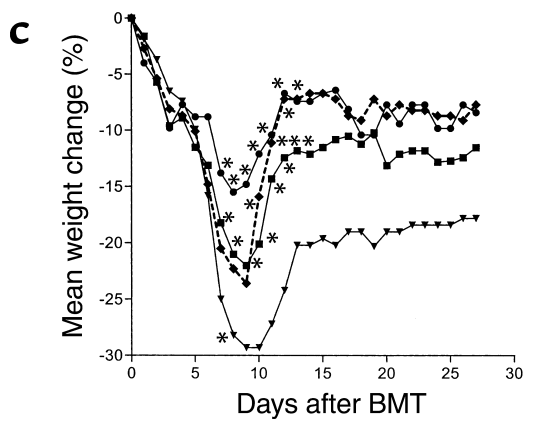

\section{Figure 1}

FTY decreases GvHD mortality and inhibits GvHD-associated weight loss. (a) GvHD mortality. (b and c) Weight curves of the syngeneic groups (b) and allogeneic groups (c). Lethally irradiated B6D2F1 mice received haplotype-mismatched GvHD-inducing C3D2F1 BMCs $\left(5 \times 10^{6}\right)$ and spleen cells $\left(1 \times 10^{6}\right)$, as well as daily treatment, by oral gavage on days $0-29$ post-BMT, with either $\mathrm{H}_{2} \mathrm{O}($ filled inverted triangles; $n=10$ ) or FTY at a dose of $3 \mathrm{mg} / \mathrm{kg}$ (filled circles; $n=10$ ), $1 \mathrm{mg} / \mathrm{kg}$ (filled squares; $n=10$ ), or $0.1 \mathrm{mg} / \mathrm{kg}$ (filled diamonds; $n=10$ ). Syngeneic control groups received $5 \times 10^{6} \mathrm{~B} 6 \mathrm{D} 2 \mathrm{~F} 1 \mathrm{BMCs}$ and either $\mathrm{H}_{2} \mathrm{O}$ (open inverted triangles; $\left.n=5\right)$ or different doses of FTY $(3 \mathrm{mg} / \mathrm{kg}$, open circles, $n=5 ; 1 \mathrm{mg} / \mathrm{kg}$, open squares, $n=5$; or $0.1 \mathrm{mg} / \mathrm{kg}$, open diamonds, $n=5)$. ${ }^{*}$ Statistically significant difference compared with $\mathrm{H}_{2} \mathrm{O}$-treated control group $(P<0.05)$.

mice in this group survived more than 29 days. In contrast, all recipients of FTY at a dose of $3 \mathrm{mg} / \mathrm{kg}(n=10)$ or $1 \mathrm{mg} / \mathrm{kg}(n=10)$ survived more than 29 days $\left(P<0.05\right.$ vs. allogeneic BMT with $\left.\mathrm{H}_{2} \mathrm{O}\right)$. Three of ten recipients of the lowest dose of FTY $(0.1 \mathrm{mg} / \mathrm{kg})$ died by day 10 post-BMT, and the remainder of the group survived more than 29 days. The syngeneic control groups receiving either $\mathrm{H}_{2} \mathrm{O}$ or different doses of FTY $(3 \mathrm{mg} / \mathrm{kg} / \mathrm{d}, n=5 ; 1 \mathrm{mg} / \mathrm{kg} / \mathrm{d}, n=5 ; 0.1 \mathrm{mg} / \mathrm{kg} / \mathrm{d}, n=5)$ all survived more than 29 days. Therefore, treatment with FTY at a daily dose of 3 or $1 \mathrm{mg} / \mathrm{kg} / \mathrm{d}$ led to a decreased rate of mortality associated with haplotypemismatched allogeneic marrow and spleen cell transplantation. The lowest dose of FTY $(0.1 \mathrm{mg} / \mathrm{kg} / \mathrm{d})$ showed only weak protective activity.

We monitored all transplanted animals for clinical signs of GvHD. Figure 1, b and c, shows the average weight changes of the groups compared with those on day -1 pre-BMT. All transplanted animals, including syngeneic controls, showed initial weight loss. All syngeneic control groups later recovered their weights (Figure 1b). Control animals receiving allogeneic BMT without FTY rapidly lost more weight than syngeneic controls until day 9 post-BMT. The survivors began to regain weight on day 11 post-BMT $(P<0.05$ on day 10 post-BMT vs. syngeneic BMT recipients treated with $\mathrm{H}_{2} \mathrm{O}$ ) (Figure 1c). The maximum weight loss of the allogeneic control animals receiving only $\mathrm{H}_{2} \mathrm{O}$ was significantly greater than that in the group receiving allogeneic BMT and FTY at a daily dose of $3 \mathrm{mg} / \mathrm{kg}(P<0.05$ on days $7-13$ post-BMT), $1 \mathrm{mg} / \mathrm{kg}(P<0.05$ on days 7-14 post-BMT), or $0.1 \mathrm{mg} / \mathrm{kg}(P<0.05$ on days $10-12$ post-BMT), and the group receiving $3 \mathrm{mg} / \mathrm{kg}$ FTY showed less weight loss than did the groups treated with 1 or $0.1 \mathrm{mg} / \mathrm{kg} / \mathrm{d}(P<0.05)$ (Figure 1c). Thus, FTY at a dose of 3,1 , or $0.1 \mathrm{mg} / \mathrm{kg} / \mathrm{d}$ alleviated GvHD-associated weight loss in a dose-related fashion.

Examination for generalized signs of GvHD (fur texture, posture, and inflammation of the eyes) revealed higher GvHD scores for the GvHD control group receiving allogeneic bone marrow and spleen cells (BMCs/SPCs) with $\mathrm{H}_{2} \mathrm{O}$ compared with the FTY-treated allogeneic groups. By day 8 , the maximum mean GvHD score of $6.58 \pm 0.42$ was reached in the allogeneic GvHD control group, and all animals had diarrhea (Table 1). The group receiving allogeneic BMCs $/$ SPCs and the lowest dose of FTY $(0.1 \mathrm{mg} / \mathrm{kg} / \mathrm{d})$ showed a maximum mean GvHD score of $5 \pm 0$ on day 7 , with diarrhea in only two of ten animals. The recipients of allogeneic BMCs/SPCs and FTY at a dose of 3 $\mathrm{mg} / \mathrm{kg} / \mathrm{d}$ or $1 \mathrm{mg} / \mathrm{kg} / \mathrm{d}$ showed further reductions in GvHD. The group receiving $3 \mathrm{mg} / \mathrm{kg} / \mathrm{d}$ FTY had a maximum mean GvHD score of $3 \pm 0$ on days 9,12 , and 13 , with no diarrhea in any of the animals $(n=10)$. The group receiving FTY at a dose of $1 \mathrm{mg} / \mathrm{kg} / \mathrm{d}$ had a maximum mean GvHD score of 2 on days 8 and 9 , and two of ten animals had diarrhea on day 9 . All clinical signs of GvHD resolved by day 18 post-BMT in all groups. Thus, FTY at a dose of $3 \mathrm{mg} / \mathrm{kg} / \mathrm{d}$ and 1 $\mathrm{mg} / \mathrm{kg} / \mathrm{d}$ led to a marked reduction in the severity of GvHD-associated clinical signs.

In order to explore the potential of FTY to inhibit a more rapidly lethal form of GvHD, we lethally irradiated B6D2F1 (H2 $\left.{ }^{\text {bxd }}\right)$ mice $(9.75 \mathrm{~Gy})$ and reconstituted them with either syngeneic bone marrow $\left(5 \times 10^{6}\right.$ cells i.v.) for hematopoietic rescue, or haplotype-mismatched allogeneic marrow $\left(5 \times 10^{6}\right.$ cells $)$ with an increased spleen cell inoculum $\left(3 \times 10^{6}\right.$ cells $)$ from C3D2F1 $\left(\mathrm{H} 2^{\mathrm{kxd}}\right)$ mice. To determine whether the presence of high levels of FTY at the time of transplant could better ameliorate GvHD, we included groups in which the administration of FTY was initiated on day -2 pre-BMT. To determine whether an augmented dose would further impede GvHD, we also evaluated a dose of $6 \mathrm{mg} / \mathrm{kg} / \mathrm{d}$ of FTY. In groups receiving these doses starting on day -2 or day 0, FTY was continued until day 29 post-BMT. In order to determine whether continuation of treatment with FTY was required to maintain freedom from 
GvHD in the group receiving FTY at a dose of 3 $\mathrm{mg} / \mathrm{kg} / \mathrm{d}$ beginning on the day of BMT, we discontinued FTY administration in about half of the mice $(n=3)$ on day 29 and continued it in the remaining animals until day 100 post-BMT $(n=4)$.

In these recipients of higher spleen cell doses, mortality in the control group receiving only sterile $\mathrm{H}_{2} \mathrm{O}$ began on day 6 post-BMT (Figure 2a), and ten of ten mice succumbed by day 7 . In contrast, recipients of 3 $\mathrm{mg} / \mathrm{kg} / \mathrm{d}$ FTY beginning on day 0 , with discontinuation on day 29 or day 100 , were almost completely protected from GvHD mortality $(P<0.05$ vs. allogeneic BMT with $\mathrm{H}_{2} \mathrm{O}$ ). Recipients of 3 or $6 \mathrm{mg} / \mathrm{kg} / \mathrm{d}$ FTY from day -2 until day 29 showed similar protection from GvHD mortality to that observed in recipients of $3 \mathrm{mg} / \mathrm{kg} / \mathrm{d}$ FTY beginning on day 0 .

The corresponding average weight changes compared with those on day 0 are shown in Figure 2, b and c. All experimental animals showed initial weight loss, but the control animals receiving only allogeneic BMCs/SPCs showed the greatest weight loss before they died. In contrast, all FTY-treated animals, regardless of the dose or time of initiation of administration, showed similar weight loss until day 7 post-BMT, then began to recover their weights on day 10. Beginning FTY on day -2 , with or without an increase in dose to 6 $\mathrm{mg} / \mathrm{kg} / \mathrm{d}$, did not further attenuate the weight loss compared with that observed in recipients of 3 $\mathrm{mg} / \mathrm{kg} / \mathrm{d}$ FTY beginning on day 0 (Figure $2 \mathrm{c}$ ). Continuing the administration of FTY beyond day 29 did not result in any measurable difference in weight by day 100 compared with that of FTY-treated allogeneic recipients in which FTY was discontinued on day 29 (Figure 2c). The syngeneic controls treated with FTY (3 or $6 \mathrm{mg} / \mathrm{kg} / \mathrm{d}$ ) or water showed similar, milder weight loss compared with the allogeneic BMT recipients and showed recovery and continuous weight increases regardless of FTY dose (Figure 2b).

In the group receiving allogeneic BMT with water alone, the mean GvHD score on day 6 was $2.5 \pm 0.24$ of a possible score of 11 , and all animals died the following day. The GvHD scores of the recipients of allogeneic BMCs/SPCs and FTY at a daily dose of $3 \mathrm{mg} / \mathrm{kg}$ starting on day $-2(1 \pm 0)$ or day $0(2 \pm 0)$ or $6 \mathrm{mg} / \mathrm{kg}$ beginning on day $-2(1 \pm 0)$ were reduced on day 6 , and clinical signs of GvHD resolved by day 15 post-BMT in all surviving groups (data not shown). Only one animal (receiving the highest dose of $6 \mathrm{mg} / \mathrm{kg} / \mathrm{d}$ from day -2 until day 29) showed any subsequent evidence of GvHD. Neither starting administration prior to the day of BMT nor increasing the dose of FTY led to further protection above the potent inhibition of GvHD observed with FTY administered at a dose of 3 $\mathrm{mg} / \mathrm{kg} / \mathrm{d}$ from days $0-29$.

FTY reduces GvHD-associated tissue infiltration. To evaluate our hypothesis that FTY could reduce GvHD-associated tissue infiltration, we lethally irradiated B6D2F1 $\left(\mathrm{H} 2^{\mathrm{bxd}}\right)$ mice $(9.75 \mathrm{~Gy})$ and reconstituted them with either syngeneic BMCs $\left(5 \times 10^{6}\right)$ and syngeneic spleen cells $\left(1 \times 10^{6}\right)(n=2)$, or haplotype-mismatched GvHDinducing allogeneic BMCs $\left(5 \times 10^{6}\right)$ and spleen cells $\left(1 \times 10^{6}\right)$ from C3D2F1 $\left(\mathrm{H} 2^{\mathrm{kxd}}\right)$ mice with $(n=7)$ or without $(n=7)$ FTY at a dose of $3 \mathrm{mg} / \mathrm{kg} / \mathrm{d}$ beginning on day 0 . Animals were sacrificed on day 11 or 13 , and tissues (skin, lung, liver, and small and large bowel) were preserved for histological analysis. Tissue infiltration consisting of lymphocytes, macrophages, and neutrophils was assessed as mild, moderate, or severe. In the untreated allogeneic group, two of three mice sacrificed on day 11 showed severe large-intestinal infiltration consisting

Table 1

Clinically reduced GvHD after FTY at a dose of 3 or $1 \mathrm{mg} / \mathrm{kg} / \mathrm{d}$

\begin{tabular}{|c|c|c|c|c|c|c|c|c|c|c|c|c|}
\hline \multirow{2}{*}{$\begin{array}{l}\text { Treatment } \\
\text { Days } \\
\text { after } \\
\text { BMT }\end{array}$} & \multirow[b]{2}{*}{$\begin{array}{c}\text { Total } \\
\text { GvHD } \\
\text { score }\end{array}$} & \multicolumn{2}{|l|}{$\mathrm{H}_{2} \mathrm{O}$} & \multicolumn{3}{|c|}{$\mathrm{FTY}(3 \mathrm{mg} / \mathrm{kg} / \mathrm{d})$} & \multicolumn{3}{|c|}{$\mathrm{FTY}(1 \mathrm{mg} / \mathrm{kg} / \mathrm{d})$} & \multicolumn{3}{|c|}{$\mathrm{FTY}(0.1 \mathrm{mg} / \mathrm{kg} / \mathrm{d})$} \\
\hline & & Diarrhea & Survival & $\begin{array}{c}\text { Total } \\
\text { GvHD } \\
\text { score }\end{array}$ & Diarrhea & Survival & $\begin{array}{c}\text { Total } \\
\text { GvHD } \\
\text { score }\end{array}$ & Diarrhea & Survival & $\begin{array}{c}\text { Total } \\
\text { GvHD } \\
\text { score }\end{array}$ & Diarrhea & Survival \\
\hline 7 & 5.1 & $4 / 7$ & $7 / 10$ & 2 & 0 & $10 / 10$ & 1 & 0 & $10 / 10$ & 5 & $02 / 10$ & $10 / 10$ \\
\hline 8 & 6.6 & $7 / 7$ & $7 / 10$ & 1 & 0 & $10 / 10$ & 2 & $01 / 10$ & $10 / 10$ & 4 & $01 / 09$ & $9 / 10$ \\
\hline 9 & 6 & $3 / 6$ & $6 / 10$ & 3 & 0 & $10 / 10$ & 2 & $02 / 10$ & $10 / 10$ & 4 & 0 & $8 / 10$ \\
\hline 10 & 5.4 & $2 / 6$ & $6 / 10$ & 2 & 0 & $10 / 10$ & 1 & 0 & $10 / 10$ & 2.3 & 0 & $7 / 10$ \\
\hline 11 & 5.8 & $1 / 6$ & $6 / 10$ & 2 & 0 & $10 / 10$ & 1 & 0 & $10 / 10$ & 1 & 0 & $7 / 10$ \\
\hline 12 & 4.7 & $1 / 6$ & $6 / 10$ & 3 & 0 & $10 / 10$ & 1 & 0 & $10 / 10$ & 1 & 0 & $7 / 10$ \\
\hline 13 & 3.4 & 0 & $5 / 10$ & 3 & 0 & $10 / 10$ & 1 & 0 & $10 / 10$ & 2.1 & 0 & $7 / 10$ \\
\hline 14 & 1.8 & 0 & $5 / 10$ & 2 & 0 & $10 / 10$ & 1 & 0 & $10 / 10$ & 1 & 0 & $7 / 10$ \\
\hline 15 & 1 & 0 & $5 / 10$ & 0 & 0 & $10 / 10$ & 0 & 0 & $10 / 10$ & 1 & 0 & $7 / 10$ \\
\hline 16 & 0 & 0 & $5 / 10$ & 0 & 0 & $10 / 10$ & 0 & 0 & $10 / 10$ & 1 & 0 & $7 / 10$ \\
\hline 17 & 1 & 0 & $5 / 10$ & 1 & 0 & $10 / 10$ & 0 & 0 & $10 / 10$ & 1 & 0 & $7 / 10$ \\
\hline 18 & 0 & 0 & $5 / 10$ & 0 & 0 & $10 / 10$ & 0 & 0 & $10 / 10$ & 0 & 0 & $7 / 10$ \\
\hline
\end{tabular}

Lethally irradiated B6D2F1 mice received haplotype-mismatched C3D2F1 BMCs $\left(5 \times 10^{6}\right)$ and spleen cells $\left(1 \times 10^{6}\right)$, as well as daily treatment, by oral gavage on days $0-29$ post-BMT, with either $\mathrm{H}_{2} \mathrm{O}(n=10)$ or FTY at a dose of $3 \mathrm{mg} / \mathrm{kg}(n=10), 1 \mathrm{mg} / \mathrm{kg}(n=10)$, or $0.1 \mathrm{mg} / \mathrm{kg}(n=10)$. Then the mice were scored for clinical evidence of GvHD by assessment of changes in skin (alopecia and inflamed or scaly skin), generalized signs (fur texture, posture, and inflammation of the eyes), and diarrhea. Shown are the average scores of the groups receiving allogeneic C3D2F1 bone marrow and spleen cells. The syngeneic control groups with or without FTY treatment remained healthy. 


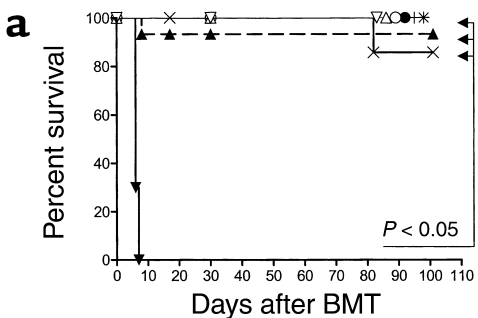

Days after BMT
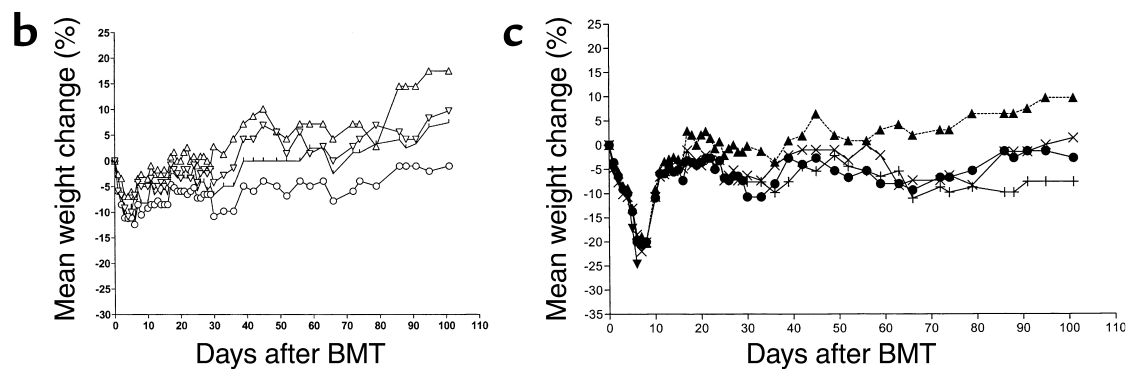

\section{Figure 2}

FTY inhibits GvHD induced by a rapidly lethal dose of allogeneic spleen cells. (a) GvHD mortality. (b and c) Weight curves of the syngeneic (b) and allogeneic (c) groups. Lethally irradiated B6D2F1 mice received haplotype-mismatched C3D2F1 BMCs $\left(5 \times 10^{6}\right)$ and an increased dose of spleen cells $\left(3 \times 10^{6}\right)$, as well as $\mathrm{H}_{2} \mathrm{O}$ (filled inverted triangles; $\left.n=10\right)$ or FTY at a dose of $3 \mathrm{mg} / \mathrm{kg}$ (filled triangles; $n=10$ ) or $6 \mathrm{mg} / \mathrm{kg}$ ( $\left.\times^{\prime} \mathrm{s} ; n=7\right)$, from day -2 pre-BMT until day 29 post-BMT. FTY was given at a dose of $3 \mathrm{mg} / \mathrm{kg}$ beginning on day 0 to an additional allogeneic group until day 29 post-BMT (filled circles; $n=3$ ), or until day 100 post-BMT (+'s; $n=4$ ). Syngeneic control groups received $5 \times 10^{6} \mathrm{~B} 6 \mathrm{D} 2 \mathrm{~F} 1$ $\mathrm{BMCs}$, as well as $\mathrm{H}_{2} \mathrm{O}$ (open inverted triangles; $\left.n=5\right)$, different doses of FTY from day -2 until day 29 ( $3 \mathrm{mg} / \mathrm{kg}$, open triangles, $n=5$; $6 \mathrm{mg} / \mathrm{kg}$, asterisks, $n=5$ ), or $3 \mathrm{mg} / \mathrm{kg}$ FTY from day 0 until day 29 (open circles; $n=5$ ).

of lymphocytes, macrophages, and neutrophils, thickening of the mucosa, and loss of crypts, and the third animal showed moderate infiltration. In contrast, in the allogeneic group receiving FTY, three of three mice showed only mild focal infiltration, with preserved crypts, less thickening of mucosa, and a few localized areas with loss of crypts and tissue infiltration, demonstrating a marked decrease in tissue pathology with FTY treatment. Among the untreated allogeneic control $\mathrm{BMC} / \mathrm{SPC}$ recipients sacrificed on day 13 , three of four animals showed severe, and the fourth animal showed moderate, inflammatory cell infiltration of the large bowel. In marked contrast, only one of four FTY-treated allogeneic recipients showed moderate infiltration, two of four showed mild focal infiltration, and one animal showed no pathological changes at all. Figure 3 depicts large-bowel tissues of representative animals from the syngeneic control group (Figure 3a), the untreated allogeneic group (Figure 3b), and the FTYtreated allogeneic group (Figure 3c), sacrificed on day 13. Syngeneic BMC/SPC control recipients showed no pathological changes on days 11 and 13, indicating recovery of the large intestine from the conditioning treatment. Liver, lung, and skin were normal in syn- geneic and allogeneic groups on days 11 and 13 , and the small intestine was largely unaffected in both allogeneic groups. Weight loss was more severe in the untreated than in the FTY-treated allogeneic group $(P<0.05$ on day 10). These analyses demonstrate that FTY attenuates tissue infiltration associated with GvHD.

$G v L$ effects proceed unbindered, while FTY inbibits GvHD. To determine whether inhibition of GvHD by FTY would be associated with impaired GvL effects, we used a previously established $\mathrm{T}$ cell leukemia/lymphoma, EL4 (52). This $\mathrm{H} 2^{\mathrm{b}}$ tumor is matched to the unshared host MHC haplotype. We lethally irradiated B6D2F1 $\left(\mathrm{H} 2^{\text {bxd }}\right)$ mice $(9.75 \mathrm{~Gy})$ and administered either syngeneic marrow $\left(5 \times 10^{6}\right.$ cells i.v.) for hematopoietic rescue, or an inoculum of haplotype-mismatched GvHDinducing allogeneic marrow cells $\left(5 \times 10^{6}\right)$ and spleen cells $\left(3 \times 10^{6}\right)$ from C3D2F1 $\left(\mathrm{H} 2^{\mathrm{kxd}}\right)$ mice; both groups also received 5,000 EL4 cells on the day of BMT. GvHD control groups received similar inocula without EL4. Mortality induced by EL4 cells in the syngeneic control group receiving only $\mathrm{H}_{2} \mathrm{O}$ began on day 19 postBMT. Median survival time (MST) was 19 days, and five of five mice died by day 21 post-BMT (Figure 4b). Similarly, the syngeneic BMT group receiving EL4 a

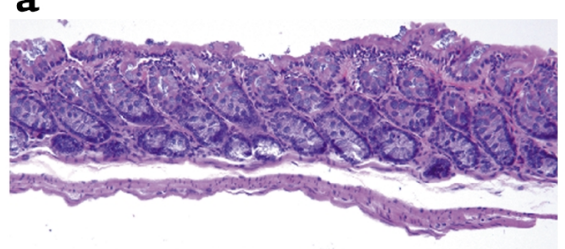

b

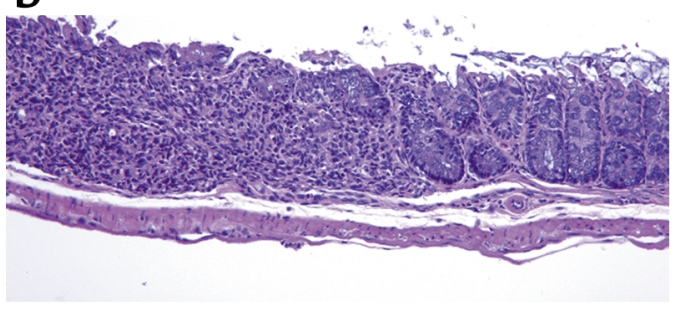

c

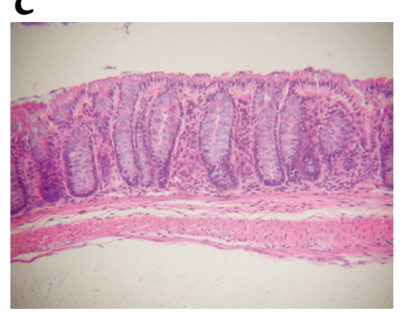

\section{Figure 3}

FTY reduces GvHD-associated tissue infiltration. Large-bowel tissues are shown $(\times 50)$ from one representative animal in each group. Lethally irradiated B6D2F1 mice (9.75 Gy) were reconstituted with either syngeneic BMCs $\left(5 \times 10^{6}\right)$ and spleen cells $\left(1 \times 10^{6}\right)$ for hematopoietic rescue $(n=2)$, or an inoculum of haplotype-mismatched GvHD-inducing allogeneic BMCs $\left(5 \times 10^{6}\right)$ and spleen cells $\left(1 \times 10^{6}\right)$ from C3D2F1 mice with $(n=7)$ or without $(n=7) 3 \mathrm{mg} / \mathrm{kg} / \mathrm{d}$ FTY (days $0-11$ or $0-13)$. Tissues are from representative animals of the syngeneic control group $(\mathbf{a})$, the untreated allogeneic group $(\mathbf{b})$, and the FTY-treated allogeneic group (c) that were sacrificed on day 13 post-BMT. 
tumor and FTY treatment $(3 \mathrm{mg} / \mathrm{kg} / \mathrm{d})$ showed mortality beginning on day 18 post-BMT, and six of six mice succumbed by day 21 . Therefore, FTY had no measurable antitumor effect against EL4 in mice receiving syngeneic BMT. Macroscopic examination of carcasses in these groups showed clearly enlarged lymph nodes and spleen, and nodular infiltration of spleen, liver, and kidney (data not shown), consistent with EL4-induced death (48).

The GvHD control group receiving allogeneic BMCs and $3 \times 10^{6}$ donor spleen cells began showing mortality on day 7 post-BMT, and six of seven mice died by 8 days post-BMT (Figure 4a). In contrast, all FTY-treated mice ( $3 \mathrm{mg} / \mathrm{kg}$ from day 0 to day 29 post-BMT) that received similar inocula survived until day 100 post$\operatorname{BMT}(n=9 ; P<0.05$ vs. allogeneic group without FTY treatment) (Figure 4a). The allogeneic group receiving tumor (without FTY) began showing mortality on day 6 post-BMT, apparently due to GvHD, and eight of ten mice died by day 9 post-BMT (Figure 4b). Thus, a GvL effect could not be measured in this group, presumably because of rapid GvHD mortality. While several mice in the allogeneic tumor group receiving 3 $\mathrm{mg} / \mathrm{kg} / \mathrm{d}$ FTY treatment (days $0-29$ post-BMT) died between day 5 and day 7 post-BMT, MST for the group was 32 days, and three of ten mice survived more than 100 days $(P<0.05$ vs. allogeneic tumor group without FTY treatment, and $P<0.05$ vs. syngeneic groups receiving EL4 with or without FTY) (Figure 4b). Thus, simultaneous protection from lymphoma and from GvHD mortality was observed in FTY-treated recipients of allogeneic BMCs/SPCs.

All animals showed initial weight loss (data not shown). The greatest weight loss occurred, as seen previously, in the allogeneic BMT groups that did not receive FTY treatment $(P<0.05$ vs. allogeneic group with FTY). Clinical signs of GvHD were also most severe in the group receiving allogeneic BMT with water alone: on day 7 the mean GvHD score was $6.57 \pm 0$, and all animals died by day 10 . In contrast, the average GvHD score of the recipients of allogeneic BMCs/SPCs and FTY at a dose of $3 \mathrm{mg} / \mathrm{kg} / \mathrm{d}$ (days 0-29) was lower on day $7(1.25 \pm 0)$, and all surviving animals were free of signs of GvHD by day 11 .

Thus, FTY treatment markedly inhibits GvHD mortality while allowing a significant antitumor effect to occur. Since allogeneic control mice that received tumor but not FTY died early from GvHD, an antitumor effect could only be seen in the FTY-treated mice that were protected from GvHD.

To compare the magnitude of GvL effects in allogeneic BMC/SPC recipients treated or not treated with FTY, we repeated the experiment with the allogeneic spleen cell dose $\left(1 \times 10^{6}\right)$ that did not previously cause lethal GvHD in control mice that did not receive FTY. We lethally irradiated $\mathrm{B} 6 \mathrm{D} 2 \mathrm{~F} 1\left(\mathrm{H} 2^{\text {bxd }}\right)$ mice $(9.75 \mathrm{~Gy})$ and administered either syngeneic marrow $\left(5 \times 10^{6}\right.$ cells i.v. $)$ for hematopoietic rescue, or an inoculum of haplotype-mismatched allogeneic marrow cells $\left(5 \times 10^{6}\right)$ and spleen cells $\left(1 \times 10^{6}\right)$ from C3D2F1 (H2 ${ }^{\mathrm{kxd}}$ ) mice; both groups also received 5,000 EL4 cells on the day of BMT. Control groups received similar inocula without EL4. As in other experiments, allogeneic recipients of $3 \mathrm{mg} / \mathrm{kg} / \mathrm{d}$ FTY with and without EL4 showed significantly less weight loss than the corresponding groups receiving similar inocula without FTY $(P<0.05$ on days 7 and 8 post-BMT without EL4, $P<0.05$ on days 7,9 , and 10 post-BMT with EL4). Almost all nonleukemic allogeneic control animals, with or without FTY treatment, survived until the end of the experiment, permitting comparison of GvL effects in untreated and FTY-treated allogeneic recipients. EL4-induced mortality in the syngeneic control group began on day 19 post-BMT, and seven of seven animals succumbed by day 21 post-BMT (Figure $5 \mathrm{a}$ ). In contrast, in the allogeneic group receiving EL4 cells and $\mathrm{H}_{2} \mathrm{O}$, leukemic mortality began 21 days post-BMT, MST was 50 days, and six of ten animals died by day 50 post-BMT $(P<0.05$ vs. syngeneic BMT with EL4). Thus, allogeneic BMC/SPC administration significantly delayed and reduced the mortality associated with EL4, as we have previously reported (48). In this experiment, mortality in the FTY-treated allogeneic recipients was similar to that in the allogeneic group receiving EL4 cells and sterile $\mathrm{H}_{2} \mathrm{O}$ only. Leukemic mortality in the FTY-treated group began on day 25 post-BMT, MST was 32 days, and seven of ten animals died by day 42 post-BMT $(P<0.05$ vs. syngeneic BMT with EL4; no significant difference vs. allogeneic BMT with EL4 and $\mathrm{H}_{2} \mathrm{O}$ ) (Figure 5a). Thus, results of this experiment indicated that the magnitude of the GvL effect in mice receiving FTY was similar to that in the group receiving
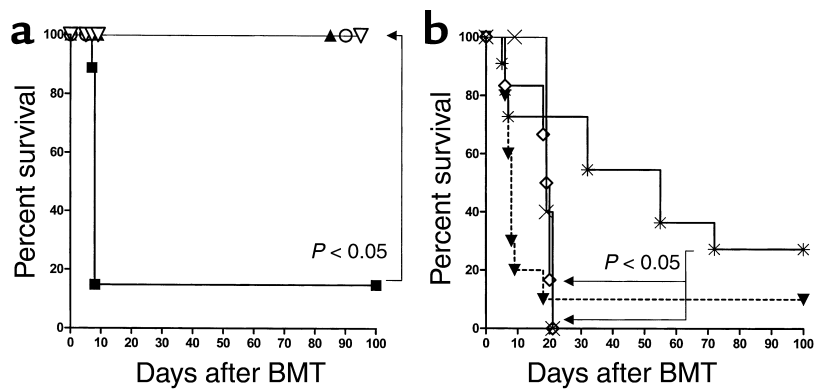

\section{Figure 4}

FTY inhibits GvHD mortality while permitting GvL effects to be observed. Survival curves of nonleukemic control groups (a) and leukemic groups (b) are shown. (a) Nonleukemic groups received syngeneic B6D2F1 BMCs $\left(5 \times 10^{6}\right)$ with either $\mathrm{H}_{2} \mathrm{O}$ (open inverted triangles; $n=7)$ or FTY ( $3 \mathrm{mg} / \mathrm{kg} / \mathrm{d}$; open circles; $n=4)$; or they received allogeneic haplotype-mismatched C3D2F1 BMCs $\left(5 \times 10^{6}\right)$ and spleen cells $\left(3 \times 10^{6}\right)$ with either $\mathrm{H}_{2} \mathrm{O}$ (filled squares; $n=10$ ) or $3 \mathrm{mg} / \mathrm{kg} / \mathrm{d}$ FTY from day 0 until day 29 post-BMT (filled triangles; $n=10)$. (b) Leukemic groups received 5,000 EL4 cells on day 0 . Mice received $5 \times 10^{6}$ syngeneic B6D2F1 BMCs alone $\left(X^{\prime} s ; n=6\right)$ or with FTY $(3 \mathrm{mg} / \mathrm{kg} / \mathrm{d}$; open diamonds; $n=6)$. Allogeneic groups received haplotype-mismatched C3D2F1 BMCs $\left(5 \times 10^{6}\right)$ and spleen cells $\left(1 \times 10^{6}\right)$ with either $\mathrm{H}_{2} \mathrm{O}$ (filled inverted triangles; $n=10$ ) or FTY treatment $\left({ }^{*} ; n=10\right)$. 

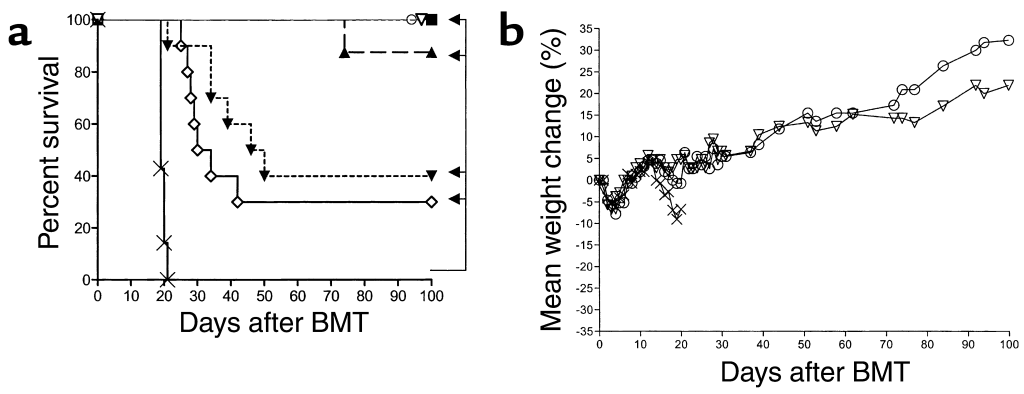

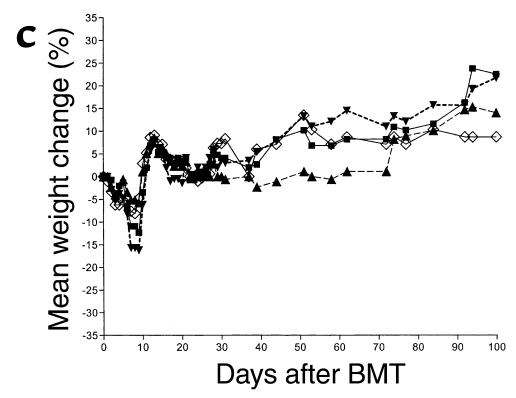

\begin{abstract}
Figure 5
FTY reduces clinical GvHD while preserving GvL. (a) Mortality. (b and c) Weight curves of the syngeneic (b) and allogeneic (c) groups. Lethally irradiated B6D2F1 mice received haplotype-mismatched allogeneic C3D2F1 BMCs $\left(5 \times 10^{6}\right)$ and spleen cells $\left(1 \times 10^{6}\right)$, with either $\mathrm{H}_{2} \mathrm{O}$ (filled squares; $n=10$ ) or $3 \mathrm{mg} / \mathrm{kg}$ FTY treatment from day 0 until day 29 post-BMT (filled triangles; $n=10$ ). Five thousand EL4 cells were administered to allogeneic groups on the day of BMT with $\mathrm{H}_{2} \mathrm{O}$ (filled inverted triangles; $n=10$ ) or with FTY treatment (open diamonds; $n=10$ ). Syngeneic control groups received $5 \times 10^{6} \mathrm{~B} 6 \mathrm{D} 2 \mathrm{~F} 1 \mathrm{BMCs}$ with $\mathrm{H}_{2} \mathrm{O}$ (open inverted triangles; $n=5$ ), with FTY $(3 \mathrm{mg} / \mathrm{kg}$; open circles; $n=5)$, or with 5,000 EL4 cells ( $\times$ 's; $n=5)$.
\end{abstract}

allogeneic BMT with no GvHD prophylaxis. This observation was confirmed in another experiment involving administration of 2,000 or 5,000 EL4 cells (data not shown).

To determine whether the tumor had been completely eradicated in the surviving allogeneic BMC/SPC recipients of EL4, we performed an adoptive transfer of spleen cells from individual surviving animals that had received allogeneic BMCs, spleen cells, and EL4 with $(n=3)$ or without $(n=4) 3 \mathrm{mg} / \mathrm{kg}$ FTY, into lethally irradiated host-type B6D2F1 secondary recipients. To eliminate any donor $\mathrm{T}$ cells that might have mediated an ongoing GvL effect at the time of sacrifice, these $T$ cells were depleted ex vivo from both spleen cell and BMC inocula before transfer to secondary recipients. To ensure that residual donor $\mathrm{T}$ cells did not survive in the secondary recipients, these mice were treated with $\mathrm{T}$ cell-depleting mAb's (anti-CD4 mAb GK1.5, antiLy2.2 mAb 2.43, and anti Ly2.1 mAb 116-13.1) on day -1 with respect to the cell transfer. EL4 does not express CD4 or CD8 (data not shown). All of the T cell-depleted BMCs and spleen cells from each experimental mouse were administered to a single B6D2F1 secondary recipient. As a control, one recipient was given $\mathrm{T}$ cell-depleted BMCs $\left(5 \times 10^{6}\right)$ and spleen cells $\left(1 \times 10^{6}\right)$ from a normal C3D2F1 donor. All recipients survived and remained healthy until day 100 post-BMT, when the experiment was terminated. These results suggest that EL4 had been completely eradicated in the original full-haplotype MHC-disparate BMT recipients treated or not treated with FTY (data not shown).

A therapentic dose of FTY does not directly reduce EL4 proliferation or migration in vivo. We addressed the possibility that the antitumor effects observed in FTY-treated mice reflected, in part, a direct effect of FTY on EL4 tumor proliferation or migration into tissues. Thirty thousand EL4 cells were administered to normal B6 mice, which were sacrificed $5,10,17$, or 24 days later ( $n=3$ per group per time point). Treatment with 3 $\mathrm{mg} / \mathrm{kg} / \mathrm{d}$ FTY for the duration of the experiment did not diminish the number of $\mathrm{V} \beta 12^{+} \mathrm{Thy} 1^{+}$EL4 cells in the lymphoid tissues and did not delay or decrease the level of tumor infiltration in other tissues (kidney, liver, and lungs) compared with that in controls receiving EL4 with $\mathrm{H}_{2} \mathrm{O}$ treatment alone (data not shown). Thus, FTY had no direct antitumor effect on EL4 and did not decrease its migration into nonlymphoid organs.

FTY does not directly sensitize EL4 to alloreactive cytotoxic T lymphocytes. FTY has been reported to have a direct toxic effect on human and mouse tumor cell lines in vitro (53-56). Although the above studies in normal B6 mice and syngeneic BMT recipients rule out a direct antitumor effect of FTY in vivo, we performed an in vitro experiment to address the possibility that the drug might enhance the sensitivity of EL4 cells to killing by alloreactive cytotoxic T lymphocytes (CTLs), which we have previously shown to be the major effectors of GvL in the EL4 model (51). BALB/c anti-B6 CTLs were generated using standard techniques (57), and cytolytic activity was assessed using EL4 targets that were cultured in medium alone, or with $0.5,1$, or $2 \mu \mathrm{M}$ FTY (concentrations similar to those used in the studies cited above; ref. 56) for the last 4 hours before ${ }^{51} \mathrm{Cr}$ labeling. In two similar experiments, culture with FTY did not affect the lysis of EL4 by alloreactive CTLs compared with that of EL4 cultured in medium alone (data not shown).

A GvHD-inbibitory dose of FTY does not prevent donormarrow engraftment. To determine whether full donor chimerism developed in animals protected from GvHD by FTY, chimerism was evaluated by FACS analysis of the peripheral WBCs on day 63 post-BMT in the FTYtreated animals presented in Figure 2. The results confirmed that the animals that received allogeneic BMCs/SPCs and that were protected from GvHD by FTY, regardless of dose or mode of administration, reconstituted fully with donor-type WBCs in all lineages (data not shown). Thus, FTY inhibits GvHD induced by allogeneic BMCs/SPCs while permitting full donor-type hematopoietic reconstitution. 


\section{Discussion}

Despite attempts to prevent GvHD by the prophylactic use of immunosuppressive drugs (3), GvHD remains a major cause of morbidity and mortality in patients undergoing allogeneic bone marrow transplantation $(14,15)$. Since GvH alloreactivity induces both detrimental GvHD and desired GvL effects, the goal of separating GvHD and GvL is of major importance. The strength of the alloresponse across MHC barriers, combined with the greater availability of haploidentical than of closely HLA-matched donors, makes the separation of GvHD and GvL effects across full-haplotype MHC barriers particularly desirable. We have previously shown that this can be achieved by administering DLI after the recipient has recovered from conditioning-induced inflammation and is less predisposed to develop GvHD (26-28). Conditioning such as total body irradiation induces upregulation of tissue cytokines (58), chemokines (M. Mapara and M. Sykes, unpublished observations), and adhesion molecules. These changes subside over time in the absence of GvH alloreactivity (M. Mapara and M. Sykes, unpublished observations), possibly leading to reduced migration of $\mathrm{GvH}$-reactive T cells to the target tissues, and hence to reduced propensity to develop GvHD, with increasing time after conditioning (26-28, 59-61). However, this approach to separating GvHD and GvL entails an undesirable delay before immunotherapy, in the form of DLI, is given. The studies presented here suggest that FTY can achieve a similar result, i.e., can reduce the predisposition of the GvH alloresponse to cause GvHD in the epithelial target tissues, while completely preserving the salutary GvL effect of lymphohematopoietic $\mathrm{GvH}$ reactions. Our results show that this can be achieved despite the administration of donor $T$ cells in the presence of proinflammatory conditions associated with lethal total body irradiation (58-61). The observed reduction in clinically and histologically detectable GvHD in FTY-treated mice receiving allogeneic BMCs/SPCs immediately following lethal total body irradiation suggests that FTY's powerful lymph node-trapping effect inhibits tissue infiltration under even these most proinflammatory conditions.

Our data show that FTY markedly decreases GvHD in a dose-related fashion. However, the peak effect appears to be achieved at a dose of $3 \mathrm{mg} / \mathrm{kg} / \mathrm{d}$, with no further protection seen at a higher dose of $6 \mathrm{mg} / \mathrm{kg} / \mathrm{d}$. While clinical use of FTY to prevent graft rejection usually has been in combination with other immunosuppressive agents and has involved lower FTY doses than those used in our mice $(62,63)$, doses of $3 \mathrm{mg} / \mathrm{kg} / \mathrm{d}$ have been used in nonhuman primate studies as a monotherapy with no apparent toxicity (64). A higher dose of 5 $\mathrm{mg} / \mathrm{kg} / \mathrm{d}$ (days -5 and -4 pre-BMT) in a canine nonmyeloablative BMT model induced hemorrhagic enteritis in one of five animals (65). We have not evaluated FTY in combination with other immunosuppressants such as cyclosporine, but other studies (37) show synergy between such agents (35), suggesting that a lower dose of FTY might be effective in the BMT setting as well, if used in combination with cyclosporine. Continuation of the administration beyond day 29 post-BMT did not show a beneficial effect over a limited 29-day course of FTY. This may reflect the reduced predisposition of GvH-reactive T cells to cause injury in GvHD target tissues after conditioning-induced inflammation has subsided. However, further studies are needed to address this hypothesis.

Since no difference in the magnitude of GvL effects was found between the allogeneic groups receiving tumor with or without FTY, our results demonstrate that GvL can proceed unhindered while GvHD is significantly alleviated in FTY-treated mice. Although it has been reported that FTY may have a direct effect on human and mouse tumor cell lines (53-56), a direct toxic effect of FTY on the EL4 tumor is ruled out by our in vivo studies showing that the control group receiving syngeneic BM, EL4, and FTY succumbed to the tumor in a time frame similar to that in animals receiving treatment without FTY. Furthermore, the addition of hosttype spleen cells in association with FTY administration did not lead to a measurable antitumor effect. We also demonstrated that FTY did not directly sensitize EL4 cells to killing by alloreactive (anti-H-2 $2^{\text {b }}$ CTLs in vitro and did not directly diminish EL4 proliferation or tissue migration in normal B6 mice. Thus, we can conclude that the GvL effect against EL4 in this model, as in other previously reported studies using this model (48), is dependent on a preserved $\mathrm{GvH}$ alloresponse.

The mechanism by which FTY inhibits GvHD is most likely altered lymphocyte trafficking. Increased homing into secondary lymphoid tissues, with decreased infiltration into grafted organs, has been well described in association with FTY administration, which leads to a reversible decrease in circulating lymphocytes and increased counts in secondary lymphoid tissues (38). FTY seems to induce lymph node sequestration of lymphocytes by affecting chemokine-driven cell trafficking involving CCR7 and other G-protein-coupled receptors. CCR7 is expressed on naive and central memory T cells and regulates $T$ cell recirculation to secondary lymphoid tissues $(44,66-68)$. Consistent with published results $(36,38)$, we found a reduced percentage of circulating CD4 and CD8 cells and B cells in animals receiving FTY until day 100 post-BMT compared with controls (data not shown).

Since leukemias and lymphomas reside largely within the lymphohematopoietic system, we hypothesized that FTY-induced inhibition of migration to the parenchymal tissues would not impede antitumor effects against these types of malignancies. Our results are consistent with this possibility. The demonstration that this separation of GvHD and GvL can be achieved with FTY in a haploidentical strain combination is very encouraging with respect to the potential for clinical transplantation from haploidentical related donors. The possibility of using such donors without unacceptable GvHD could greatly expand the donor pool, 
making hematopoietic stem cell transplantation available to almost all patients who could benefit from it, while allowing the enhanced GvL effects associated with MHC disparity (19) to be enjoyed.

Most other strategies for preventing and treating GvHD are globally immunosuppressive, and infectious complications have been a major barrier to their use, particularly in extensively HLA-mismatched transplants such as those involving haploidentical donors $(21,69)$. The use of FTY, on the other hand, may not cause the global immunosuppression associated with current methods of GvHD prophylaxis and treatment. Animals receiving therapeutic doses of FTY show normal primary and memory antibody responses to lymphocytic choriomeningitis virus and vesicular stomatitis virus infection and show increased numbers of virus-specific cytotoxic CD8 $\mathrm{T}$ lymphocytes in the lymph nodes, thereby allowing complete clearance of the virus. Bacterial defense seems to be intact as well $(39,70)$. Furthermore, it has been shown that FTY does not inhibit $\mathrm{T}$ cell activation and proliferation (36), cytokine production $(33,36)$, or antibody production in other settings (70). These data are consistent with the interpretation that FTY does not markedly impair $\mathrm{T}$ or $\mathrm{B}$ cell activation or differentiation, and that the preserved GvL effects while GvHD is inhibited reflect altered lymphocyte trafficking induced by this novel agent. Thus, FTY provides a possibly clinically applicable new strategy for the separation of GvHD and GvL.

\section{Acknowledgments}

This work was supported by NIH grant RO1 CA79989. We thank Orlando Moreno for excellent animal husbandry, Robin Laber for expert assistance with the manuscript, Volker Brinkmann for providing us with FTY, and Bimalangshu R. Dey and Yong-Guang Yang for helpful review of the manuscript.

1. Weiden, P.L., et al. 1979. Antileukemic effect of graft-versus-host disease in human recipients of allogeneic marrow grafts. N. Engl. J. Med. 300:1068-1073.

2. Weiden, P.L., Sullivan, K.M., Flournoy, N., Storb, R., and Thomas, E.D. 1981. Antileukemic effect of chronic graft-versus-host disease. N. Engl. J. Med. 304:1529-1533.

3. Goker, H., Haznedaroglu, I.C., and Chao, N.J. 2001. Acute graft-vs-host disease: pathobiology and management. Exp. Hematol. 29:259-277.

4. Weisdorf, D., et al. 1990. Treatment of moderate/severe acute graft-versus-host disease after allogeneic bone marrow transplantation: an analysis of clinical risk features and outcome. Blood. 75:1024-1030.

5. Martin, P.J., et al. 1990. A retrospective analysis of therapy for acute graft-versus-host disease: initial treatment. Blood. 76:1464-1472.

6. Ho, V.T., and Soiffer, R.J. 2001. The history and future of T-cell depletion as graft-versus-host disease prophylaxis for allogeneic hematopoietic stem cell transplantation. Blood. 98:3192-3204.

7. Clift, R.A., and Storb, R. 1987. Histoincompatible bone marrow transplants in humans. Annu. Rev. Immunol. 5:43-64.

8. Ratanatharathorn, V., et al. 1998. Phase III study comparing methotrexate and tacrolimus (Prograf, FK506) with methotrexate and cyclosporine for graft-versus-host disease prophylaxis after HLA-identical sibling bone marrow transplantation. Blood. 92:2303-2314.

9. Nash, R.A., et al. 2000. Phase 3 study comparing methotrexate and tacrolimus with methotrexate and cyclosporine for prophylaxis of acute graft-versus-host disease after marrow transplantation from unrelated donors. Blood. 96:2062-2068.

10. Khouri, I.F., et al. 2001. Nonablative allogeneic hematopoietic transplantation as adoptive immunotherapy for indolent lymphoma: low incidence of toxicity, acute graft-versus-host disease, and treatmentrelated mortality. Blood. 98:3595-3599.
11. Storb, R., et al. 1990. What role for prednisone in prevention of acute graft-versus-host disease in patients undergoing marrow transplants? Blood. 76:1037-1045.

12. Frassoni, F., et al. 1996. Results of allogeneic bone marrow transplantation for acute leukemia have improved in Europe with time: a report of the acute leukemia working party of the European group for blood and marrow transplantation (EBMT). Bone Marrow Transplant. 17:13-18.

13. Nademanee, A., et al. 1995. The outcome of matched unrelated donor bone marrow transplantation in patients with hematologic malignancies using molecular typing for donor selection and graft-versus-host disease prophylaxis regimen of cyclosporine, methotrexate, and prednisone. Blood. 86:1228-1234.

14. Ruutu, T., Niederwieser, D., Gratwohl, A., and Apperley, J.F. 1997. A survey of the prophylaxis and treatment of acute GVHD in Europe: a report of the European Group for Blood and Marrow, Transplantation (EBMT). Chronic Leukaemia Working Party of the EBMT. Bone Marrow Transplant. 19:759-764.

15. Bensinger, W.I., et al. 2001. Transplantation of bone marrow as compared with peripheral-blood cells from HLA-identical relatives in patients with hematologic cancers. N. Engl. J. Med. 344:175-181.

16. Butturini, A., and Gale, R.P. 1988. T cell depletion in bone marrow transplantation for leukemia: current results and future directions. Bone Marrow Transplant. 3:265-279.

17. Martin, P.J., et al. 1988. Graft failure in patients receiving T cell-depleted HLA-identical allogeneic marrow transplants. Bone Marrow Transplant. 3:445-456.

18. Aizawa, S., and Sado, T. 1991. Graft-versus-leukemia effect in MHCcompatible and -incompatible allogeneic bone marrow transplantation of radiation-induced, leukemia-bearing mice. Transplantation. 52:885-889.

19. Sykes, M., and Sachs, D.H. 1989. Genetic analysis of the anti-leukemic effect of mixed allogeneic bone marrow transplantation. Transplant. Proc. 21:3022-3024.

20. Drobyski, W.R., et al. 2002. Superior survival associated with transplantation of matched unrelated versus one-antigen-mismatched unrelated or highly human leukocyte antigen-disparate haploidentical family donor marrow grafts for the treatment of hematologic malignancies: establishing a treatment algorithm for recipients of alternative donor grafts. Blood. 99:806-814.

21. Aversa, F., et al. 1998. Treatment of high-risk acute leukemia with T celldepleted stem cells from related donors with one fully mismatched haplotype. N. Engl. J. Med. 339:1186-1193.

22. Anasetti, C., Etzioni, R., Petersdorf, E.W., Martin, P.J., and Hansen, J.A. 1995. Marrow transplantation from unrelated volunteer donors. Annu. Rev. Med. 46:169-179.

23. Martelli, M.F., et al. 2002. Transplants across human leukocyte antigen barriers. Semin. Hematol. 39:48-56.

24. Bishop, M.R., et al. 1996. Long-term survival in advanced chronic myelogenous leukemia following bone marrow transplantation from haploidentical related donors. Bone Marrow Transplant. 18:747-753.

25. Sykes, M., et al. 1999. Mixed lymphohaemopoietic chimerism and graftvs-lymphoma effects after non-myeloablative therapy and HLA-mismatched bone marrow transplantation. Lancet. 353:1755-1759.

26. Pelot, M.R., et al. 1999. Lymphohematopoietic graft-vs-host reactions can be induced without graft-vs-host disease in murine mixed chimeras established with a cyclophosphamide-based non-myeloablative conditioning regimen. Biol. Blood Marrow Transplant. 5:133-143.

27. Sykes, M., Sheard, M.A., and Sachs, D.H. 1988. Graft-versus-host-related immunosuppression is induced in mixed chimeras by alloresponses against either host or donor lymphohematopoietic cells. J. Exp. Med. 168:2391-2396.

28. Mapara, M.Y., et al. 2002. Donor lymphocyte infusions mediate superior graft-versus-leukemia effects in mixed compared to fully allogeneic chimeras: a critical role for host antigen-presenting cells. Blood. 100:1903-1909.

29. Spitzer, T.R., et al. 2000. The intentional induction of mixed chimerism and achievement of anti-tumor responses following non-myeloablative conditioning therapy and HLA-matched and mismatched donor bone marrow transplantation for refractory hematologic malignancies. Biol. Blood Marrow Transplant. 6:309-320.

30. Spitzer, T.R., et al. 2001. Mixed lymphohematopoietic chimerism and delayed donor leukocyte infusions following non-myeloablative conditioning and HLA-matched and mismatched donor bone marrow transplantation. In Autologous bone marrow transplantation: Proceedings of the 10th International Symposium. K.A. Dicke and A. Keating, editors. Carden Jennings Publishing Co. Charlottesville, Virginia, USA. 321-330.

31. Fujita, T., et al. 1996. Potent immunosuppressants, 2-alkyl-2-aminopropane-1,3-diols. J. Med. Chem. 39:4451-4459.

32. Katz, S.M., Hong, J.C., and Kahan, B.D. 2000. New immunosuppressive agents. Transplant. Proc. 32:620-621.

33. Yanagawa, Y., et al. 1998. FTY720, a novel immunosuppressant, induces sequestration of circulating mature lymphocytes by acceleration of lym- 
phocyte homing in rats. II. FTY720 prolongs skin allograft survival by decreasing $\mathrm{T}$ cell infiltration into grafts but not cytokine production in vivo. J. Immunol. 160:5493-5499.

34. Hwang, M.W., et al. 1999. FTY720, a new immunosuppressant, promotes long-term graft survival and inhibits the progression of graft coronary artery disease in a murine model of cardiac transplantation. Circulation. 100:1322-1329.

35. Hoshino, Y., et al. 1996. FTY720, a novel immunosuppressant possessing unique mechanisms. II. Long-term graft survival induction in rat heterotopic cardiac allografts and synergistic effect in combination with cyclosporine A. Transplant. Proc. 28:1060-1061.

36. Suzuki, S., et al. 1996. A novel immunosuppressant, FTY720, with a unique mechanism of action, induces long-term graft acceptance in rat and dog allotransplantation. Transplantation. 61:200-205.

37. Kawaguchi, T., et al. 1996. FTY720, a novel immunosuppressant possessing unique mechanisms. III. Synergistic prolongation of canine renal allograft survival in combination with cyclosporine A. Transplant. Proc. 28:1062-1063

38. Chiba, K., et al. 1996. FTY720, a novel immunosuppressant possessing unique mechanisms. I. Prolongation of skin allograft survival and synergistic effect in combination with cyclosporine in rats. Transplant. Proc. 28:1056-1059.

39. Brinkmann, V., Pinschewer, D., Chiba, K., and Feng, L. 2000. FTY720: a novel transplantation drug that modulates lymphocyte traffic rather than activation. Trends Pharmacol. 21:49-52.

40. Masubuchi, Y., et al. 1996. FTY720, a novel immunosuppressant, possessing unique mechanisms. IV. Prevention of graft versus host reactions in rats. Transplant. Proc. 28:1064-1065.

41. Mitsusada, M., et al. 1997. Prevention of graft rejection and graft-versushost reaction by a novel immunosuppressant, FTY720, in rat small bowel transplantation. Transpl. Int. 10:343-349.

42. Mandala, S., et al. 2002. Alteration of lymphocyte trafficking by sphingosine-1-phosphate receptor agonists. Science. 296:346-349.

43. Brinkmann, V., et al. 2002. The immune modulator FTY720 targets sphingosine 1-phosphate receptors. J. Biol. Chem. 277:21453-21457.

44. Henning, G., et al. 2001. CC chemokine receptor 7-dependent and -independent pathways for lymphocyte homing: modulation by FTY720. J. Exp. Med. 194:1875-1881.

45. Sykes, M., Sheard, M., and Sachs, D.H. 1988. Effects of T cell depletion in radiation bone marrow chimeras. I. Evidence for a donor cell population which increases allogeneic chimerism but which lacks the potential to produce GVHD. J. Immunol. 141:2282-2288.

46. Sykes, M., Romick, M.L., Hoyles, K.A., and Sachs, D.H. 1990. In vivo administration of interleukin 2 plus T cell-depleted syngeneic marrow prevents graft-versus-host disease mortality and permits alloengraftment. J. Exp. Med. 171:645-658.

47. Unkeless, J.C. 1979. Characterization of a monoclonal antibody directed against mouse macrophage and lymphocyte Fc receptors. J. Exp. Med. 150:580-596.

48. Sykes, M., Romick, M.L., and Sachs, D.H. 1990. Interleukin 2 prevents graft-versus-host disease while preserving the graft-versus-leukemia effect of allogeneic T cells. Proc. Natl. Acad. Sci.U. S. A. 87:5633-5637.

49. Dialynas, D.P., et al. 1983. Characterization of murine T cell surface molecule, designated L3T4, identified by monoclonal antibody GK1.5: similarity of L3T4 to human Leu3/T4 molecule. J. Immunol. 131:2445-2451.

50. Sarmiento, M., Glasebrook, A.L., and Fitch, F.W. 1980. IgG or IgM monoclonal antibodies reactive with different determinants on the molecular complex bearing Lyt 2 antigen block T cell-mediated cytolysis in the absence of complement. J. Immunol. 125:2665-2672.

51. Sykes, M., Abraham, V.S., Harty, M.W., and Pearson, D.A. 1993. IL-2 reduces graft-vs-host disease and preserves a graft-vs-leukemia effect by selectively inhibiting CD4+ T cell activity. J. Immunol. 150:197-205.

52. Sykes, M., Bukhari, Z., and Sachs, D.H. 1989. Graft-versus-leukemia effect using mixed allogeneic bone marrow transplantation. Bone Marrow Transplant. 4:465-474.
53. Matsuda, S., Minowa, A., Suzuki, S., and Koyasu, S. 1999. Differential activation of c-Jun NH2-terminal kinase and p38 pathways during FTY720-induced apoptosis of T lymphocytes that is suppressed by the extracellular signal-regulated kinase pathway. J. Immunol. 162:3321-3326.

54. Permpongkosol, S., et al. 2002. Anticarcinogenic effect of FTY720 in human prostate carcinoma DU145 cells: modulation of mitogenic signaling, FAK, cell-cycle entry and apoptosis. Int. J. Cancer. 98:167-172.

55. Fujino, M., Li, X.K., Guo, L., Amano, T., and Suzuki, S. 2001. Activation of caspases and mitochondria in FTY720-mediated apoptosis in human T cell line Jurkat. Int. Immunopharmacol. 1:2011-2021.

56. Azuma, H., et al. 2002. Marked prevention of tumor growth and metastasis by a novel immunosuppressive agent, FTY720, in mouse breast cancer models. Cancer Res. 62:1410-1419.

57. Wekerle, T., et al. 1998. Extrathymic T cell deletion and allogeneic stem cell engraftment induced with costimulatory blockade is followed by central T cell tolerance. J. Exp. Med. 187:2037-2044.

58. Xun, C.Q., Thompson, J.S., Jennings, C.D., Brown, S.A., and Widmer, M.B. 1994. Effect of total body irradiation, busulfan-cyclophosphamide, or cyclophosphamide conditioning on inflammatory cytokine release and development of acute and chronic graft-versushost disease in H-2-incompatible transplanted SCID mice. Blood. 83:2360-2367.

59. Xun, C.Q., Tsuchida, M., and Thompson, J.S. 1997. Delaying transplantation after total body irradiation is a simple and effective way to reduce acute graft-versus-host disease mortality after major $\mathrm{H} 2$ incompatible transplantation. Transplantation. 64:297-302.

60. Johnson, B.D., Drobyski, W.R., and Truitt, R.L. 1993. Delayed infusion of normal donor cells after MHC-matched bone marrow transplantation provides an antileukemia reaction without graft-versus-host disease. Bone Marrow Transplant. 11:329-336.

61. Sykes, M., Chester, C.H., and Sachs, D.H. 1988. Protection from graftversus-host disease in fully allogeneic chimeras by prior administration of $\mathrm{T}$ cell-depleted syngeneic bone marrow. Transplantation. 46:327-330.

62. Brinkmann, V., Pinschewer, D.D., Feng, L., and Chen, S. 2001. FTY720: altered lymphocyte traffic results in allograft protection. Transplantation. 72:764-769

63. Nikolova, Z., Hof, A., Baumlin, Y., and Hof, R.P. 2001. Combined FTY720/cyclosporine treatment promotes graft survival and lowers the peripheral lymphocyte count in a murine cardiac allotransplantation model. Transplantation. 72:168-171.

64. Schuurman, H.-J., et al. 2002. Oral efficacy of the new immunomodulator FTY720 in cynomolgus monkey kidney allotransplantation, given alone or in combination with cyclosporine or RAD. Transplantation. 74:951-960.

65. Xun, C.Q., et al. 2002. What role for FTY720, a novel immunosuppressive agent, in canine nonmyeloablative hematopoietic stem cell transplantation? Transplantation. 73:310-313.

66 . Forster, R., et al. 1999. CCR7 coordinates the primary immune response by establishing functional microenvironments in secondary lymphoid organs. Cell. 99:23-33.

67. Sallusto, F., and Lanzavecchia, A. 2000. Understanding dendritic cell and T-lymphocyte traffic through the analysis of chemokine receptor expression. Immunol. Rev. 177:134-140.

68. Chen, S., et al. 2001. FTY720, a novel transplantation drug, modulates lymphocyte migratory responses to chemokines. Transplant. Proc. 33:3057-3063.

69. Volpi, I., et al. 2001. Postgrafting administration of granulocyte colony-stimulating factor impairs functional immune recovery in recipients of human leukocyte antigen haplotype-mismatched hematopoietic transplants. Blood. 97:2514-2521.

70. Pinschewer, D.D., et al. 2000. FTY720 immunosuppression impairs effector $\mathrm{T}$ cell peripheral homing without affecting induction, expansion, and memory. J. Immunol. 164:5761-5770. 